\title{
Nodule Inception Is Not Required for Arbuscular Mycorrhizal Colonization of Medicago truncatula
}

\author{
Anil Kumar ${ }^{1, \dagger}$, Donna R. Cousins ${ }^{2,+}$, Cheng-Wu Liu ${ }^{2}$, Ping $\mathrm{Xu}^{3, *}$ and Jeremy D. Murray ${ }^{1,2, *}$ \\ 1 National Key Laboratory of Plant Molecular Genetics, CAS-JIC Centre of Excellence for Plant and Microbial \\ Science (CEPAMS), CAS Center for Excellence in Molecular and Plant Sciences, Institute of Plant Physiology \\ and Ecology, Chinese Academy of Sciences, Shanghai 200032, China; anilkumar.ptu@gmail.com \\ 2 Cell and Developmental Biology, John Innes Centre, Norwich Research Park, Norwich NR4 7UH, UK; \\ donnacousins50@gmail.com (D.R.C.); chengwu.liu@slcu.cam.ac.uk (C.-W.L.) \\ 3 Shanghai Engineering Research Center of Plant Germplasm Resource, College of Life Sciences, Shanghai \\ Normal University, Shanghai 200234, China \\ * Correspondence: pingxu_ardnor@shnu.edu.cn (P.X.); jeremy.murray@jic.ac.uk (J.D.M.) \\ + These authors contributed equally.
}

Received: 2 December 2019; Accepted: 31 December 2019; Published: 6 January 2020

\begin{abstract}
Most legumes can engage in symbiosis with N-fixing bacteria called rhizobia. This symbiosis, called nodulation, evolved from the more widespread symbiosis that most land plants form with arbuscular mycorrhiza, which is reflected in a common requirement of certain genes for both these symbioses. One key nodulation gene, Nodule Inception (NIN), has been intensively studied. Mutants in NIN are unable to form nodules, which has made it difficult to identify downstream genes under the control of NIN. The analysis of data from our recent transcriptomics study revealed that some genes with an altered expression of nin during nodulation are upregulated in mycorrhizal roots. In addition, another study reported the decreased colonization of nin roots by arbuscular mycorrhiza. We therefore investigated a role for NIN in mycorrhiza formation. Our time course study, using two nin alleles with differing genetic backgrounds, suggests that that loss of NIN does not affect colonization of Medicago truncatula roots, either in the presence or absence of rhizobia. This, and recent phylogenetic analyses showing that the loss of NIN is correlated with loss of nodulation in the FaFaCuRo clade, but not with the ability to form mycorrhiza, argue against NIN being required for arbuscular mycorrhization in legumes.
\end{abstract}

Keywords: common symbiosis genes; Sinorhizobium meliloti; Rhizophagus irregularis

\section{Introduction}

Arbuscular mycorrhization is a beneficial symbiosis formed between arbuscular mycorrhizal (AM) fungi and many terrestrial plants. It is believed to be older than 400 million years old, and its retention in over $70 \%$ of land plants suggests it provides a strong selective advantage to its hosts [1]. This symbiosis promotes the uptake of phosphates and other nutrients by the plant host at the expense of host carbon, supplied to the fungal endosymbiont. It entails the constant exchange of signals between the host and symbiont, which ultimately leads to the formation of nutrient exchange and fungus-accommodation structures called arbuscules within root cortical cells [2]. This process requires the differential activation of hundreds of genes which have been studied at the evolutionary and functional genetic levels using genomic approaches [3].

A second widespread symbiosis, called nodulation, can be formed by most species belonging to the third largest plant family, the legumes (Fabaceae) with gram-negative soil bacteria collectively called rhizobia [4]. The nodulation of most legume plants involves the intracellular infection of root 
hairs by rhizobia followed by the colonization of the cortical layers of the root [5]. This symbiosis leads to the formation of special root outgrowths called nodules. Nodules are comprised mainly of cells filled with nitrogen-fixing rhizobia contained within membrane-bound structures called symbiosomes [6]. Like mycorrhization, nodulation requires ongoing signal-exchange with the rhizobia. Plant-released flavonoids trigger the production of a counter-signal by the rhizobia, a mixture of lipo-chito oligosaccharide signal molecules called Nod factors [7? ]. Nod factors are perceived by host Nod factor receptors which trigger the increased expression of several transcription factors, including Nodule Inception (NIN), ERF Required for Nodulation1 (ERN1), NFYA1, and the GRAS transcription factors Nodulation Signalling Pathway1 (NSP1) and NSP2 [8-17]. The activation of these, and other transcription factors, results in extensive transcriptional changes that lead to the formation of nitrogen fixing nodules.

Since its discovery, Nodule Inception (NIN) has been extensively studied for its role in nodulation [8]. Mutants lacking NIN respond to rhizobia by root hair deformation, but do not initiate the formation of infection threads, nor do they form nodules $[8,9,18]$. NIN is the founding member of a small family of transcription factors, called NIN-like proteins (NLPs), that are present in all plants and have homologs in algae [19]. NLPs in Arabidopsis have demonstrated roles in nitrate sensing, uptake and assimilation [20]. In legumes, two NLPs have been implicated in the nitrate suppression of nodulation [21,22], suggesting that NIN's function in positively controlling infection by rhizobia is unique within the NLP family. Interestingly, almost all members of the Fabales, Fagales, Cucurbitales and Rosales (FaFaCuRo) clade that have lost the ability to nodulate have also lost NIN, along with many other nodulation-specific genes [23,24].

Despite NIN's importance, the identification of the genes downstream of NIN was impeded by the complete lack of nodules on nin mutants. However, in recent years, direct targets of NIN were identified using chromatin immunoprecipitation in Lotus japonicus and the NIN regulon was characterized using a root-hair transcript profiling approach [25]. Amongst NIN's targets are Nodulation Pectate Lyase 1 (NPL1) [26] which is required for rhizobial infection and at least two CCAAT-box transcription factors that are associated with nodule organogenesis [15-17,27]. Indeed, NIN's regulon was estimated to include at least 120 genes [25]. Our analysis of $n i n^{\prime}$ s root hair infectome found many genes with deregulated expression in nin, relative to wild type controls, that are also upregulated in roots colonized by AM fungi. Furthermore, a recent paper found decreased mycorrhizal colonization in M. truncataula nin-1 [28]. Based on this, we investigated a potential role for NIN in nodulated and non-nodulated roots of M. truncatula.

\section{Results}

\section{1. nin Mutants Have No Obvious Mycorrhizal Phenotype}

A comparison of genes that were differentially expressed in root hairs of rhizobia-inoculated seedlings (nin-1 vs wild type) to those genes induced by Rhizophagus irregularis revealed some overlap (Supplemental S1). About 40 genes were found with decreased expression in nin and increased expression during AM colonization, and about 50 others were upregulated in both nin and mycorrhizal roots. To determine whether this could influence colonization by arbuscular mycorrhiza, either with or without nodulation, an experiment was set up using nin-1 and nin-2, that are from the M. truncatula $\mathrm{cv}$ Jemalong A17 and M. truncatula ssp. tricycla R108 backgrounds, respectively. Both nin alleles were scored over a time course of 2, 3, 4 and 5 weeks post inoculation (wpi) with R. irregularis DAOM197198 (10\% chive inoculum). Half the plants were inoculated with Sinorhizobium meliloti Rm1021. Ten plants were grown for each genotype/time point/experimental condition and root samples were harvested. Nodules were completely absent from both nin mutants in all conditions, and non-inoculated wild type plants. Rhizobia-inoculated wild type plants nodulated normally. The root samples were then stained and scored for arbuscules (Figure 1). Although some reductions in AM colonization were 
observed in certain treatments (Figure 1b), overall the results showed no consistent difference in AM colonization between WT and either nin mutant, with or without nodulation.

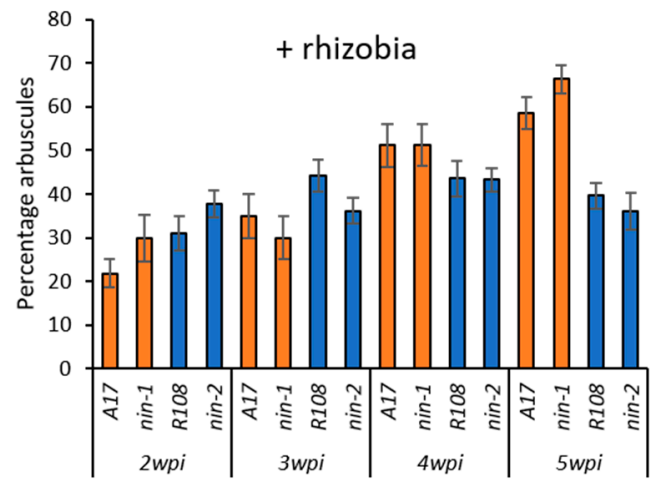

(a)

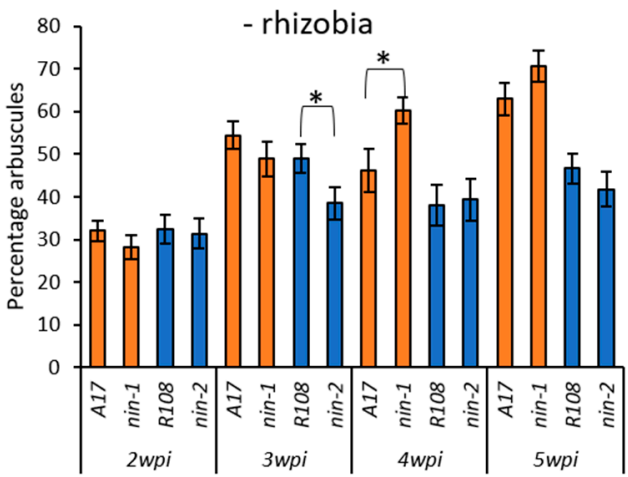

(b)

Figure 1. AM phenotype of nin mutants with and without addition of rhizobia. (a) M. truncatula plants were inoculated with $R$. irregularis (10\% chive root inoculum) and S. meliloti Rm1021 or (b) with $R$. irregularis only. The percentage of arbuscules in plants was determined at 2, 3, 4, and 5 weeks post inoculation (wpi). A17 is the WT background for nin-1, and nin-2 is in the R108 background. Bars represent the standard error of the mean. Asterisk indicates a significant difference between the indicated means (Student's $t$-test, ${ }^{*} p<0.05$ ).

\subsection{NIN Expression during Mycorrhization}

During nodulation, the NIN transcript levels are strongly increased, especially in the root hairs of rhizobia infected plants and nodules $[29,30]$. To determine if NIN is transcriptionally induced during mycorrhization, we compiled data from several RNA-seq and microarray transcriptome studies. The data were downloaded from the M. truncatula and the Lotus japonicus Gene Expression Atlas [31,32]. No difference was found in NIN expression in arbuscule cells vs adjacent cells or uncolonized cortical cells of $M$. truncatula, collected using laser capture microdissection (LCM) 3 weeks after inoculation with R. irregularis [33] (Figure 2a). A second dataset indicated that NIN expression was unchanged in 6-week-old uninoculated vs $R$. irregularis inoculated M. truncatula roots [34] (Figure 2a). To broaden our analysis, NIN expression was examined using data from a similar experiment carried out with another model legume, L. japonicus [35]. Similar to our findings in M. truncatula, no significant difference in NIN expression was detected between uninoculated and Gigaspora margarita inoculated roots at either of the two time points studied (Figure 2a). Finally, we used RNAseq data normalized across two different experiments to compare NIN expression in nodulated and mycorrhized roots, using the mycorrhiza-induced transcription factor RAM1 as a reference [36,37]. As expected, an increase in NIN expression of two orders in magnitude was observed in nodules relative to control roots (Figure 2b). In mycorrhizal roots, RAM1 was highly induced, but NIN expression was similar to baseline levels, and as before no induction of NIN in mycorrhizal roots relative to mock-inoculated controls was observed. 


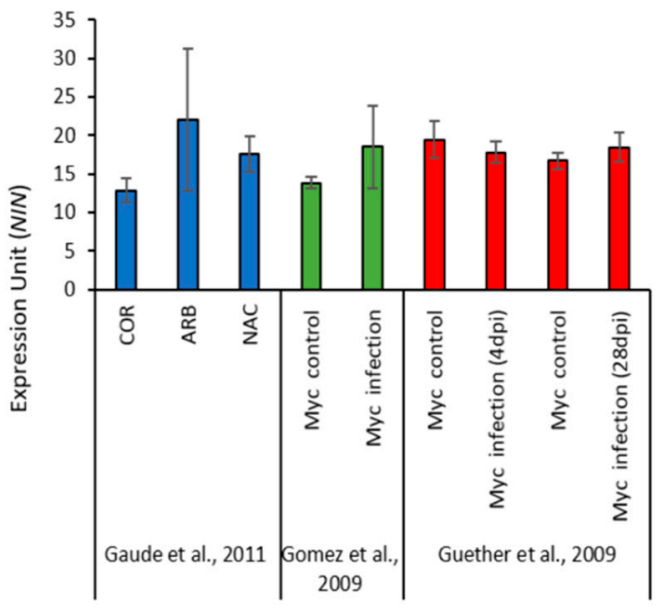

(a)

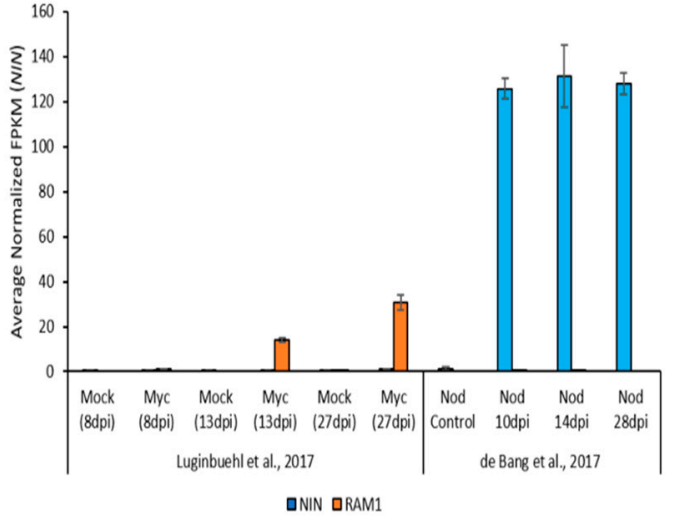

(b)

Figure 2. Expression of Nodule Inception (NIN) during AM symbiosis and nodulation. Quantification of NIN expression (a) using publicly available transcriptome data (microarray). Raw data were retrieved from the Medicago truncatula Gene Expression Atlas [31] and the Lotus japonicus Gene Expression Atlas [32]. Data from three independent experiments are shown. The chart on the left shows NIN expression in different cell types of M. truncatula, collected using laser capture microdissection (LCM) 3 weeks after inoculation with $R$. irregularis. Data are from Gaude et al. [33]. In Gomez et al. [34] chart, NIN expression in 6-week-old $M$. truncatula uninoculated and $R$. irregularis inoculated roots is shown. Guether et al. [35] data represent NIN expression in uninoculated and Gigaspora margarita inoculated roots of Lotus japonicus at two different time points 4- and 28-days post inoculation (dpi). COR-cortical cells of non-mycorrhizal roots, ARB-arbuscule-containing cells and NAC-non-colonized cortical cells of mycorrhizal roots. Error bars represent standard error of the mean; (b) Quantification of NIN expression using publicly available transcriptome data (RNAseq). Raw data were retrieved from $M$. truncatula Small Secreted Peptide Database [38]. The expression of NIN and RAM1 at different time points post inoculation with $R$. irregularis along with their respective mock inoculated controls was compared; data are from Luginbuehl et al. [37]. The expression of NIN and RAM1 at varying developmental stages of nodulation was compared; data are from de Bang et al. [36]. Error bars represent standard error of the mean.

\section{Discussion}

We investigated nin for a potential mycorrhizal colonization phenotype, but no consistent effect, either increased or decreased, was found. This suggests that NIN doesn't play a direct or indirect role in mycorrhization. The enhancement of certain mycorrhiza-induced genes in the root hairs of rhizobia-inoculated nin seedlings may be a consequence of a loss of negative feedback, leading to the increased activation of NIN-independent infection gene expression, which includes several common symbiotic genes induced both by mycorrhizal and rhizobia. NIN controls at least two negative regulators of infection in root hairs, CLE12/CLE-RS2 [39,40] directly, and several gibberellic acid biosynthesis genes [25], which act together to limit infection.

While our conclusion regarding the absence of an AM phenotype is consistent with earlier reports on nin in L. japonicus [18,41,42], it contradicts an earlier study that found that M. truncataula nin-1 had strongly reduced AM colonization at nine weeks post inoculation, and had a mild decrease in penetration events at two weeks post inoculation [28]. The differences could be accounted for by the use of different types of inoculum used. The previous study used a fixed quantity of spores as inoculum, while the inoculum used for this study was a fresh inoculum containing spores, mycelia and colonized root fragments which presumably more closely resembles what plants encounter in their natural setting. Use of spore-only inoculum typically results in a relatively slow progression of infection compared to inoculum containing active mycelia, which can enhance stochasticity of the infection, particularly at early stages which are characteristically asynchronous. Another major difference was that the previous 
study evaluated colonization at 9 weeks post infection, a time point at which colonization levels are often in decline. Factors such as the nature/efficacy of the inoculum and the plant growth conditions can greatly influence the infection dynamic and the level of biological variation-concerns that can be addressed through a time course analysis. Our conclusions are based on two mutant alleles in two different mutant backgrounds, each tested at four different timepoints ranging over a one-month period during which colonization was still increasing, reaching near maximal levels $(\sim 70 \%$ arbuscule occurrence), or had stabilized. A review of transcriptomic data from several different studies failed to support a role for NIN in mycorrhization, as no significant difference was found in NIN expression among infected and non-infected cells and between inoculated and non-inoculated cells at different time points. Furthermore, NIN has very low transcript levels in non-symbiotic roots and responds to compatible rhizobia with a large and rapid increase in expression, contrasting with its lack of response to mycorrhizal fungi. This non-responsiveness is consistent with an earlier report from L. japonicus that monitored NIN expression using qPCR over a four-point time course spanning 4 days to 4 weeks after inoculation with $R$. irregularis [43]. In the Guillotin et al. study, which reported a small increase in NIN expression in mycorrhizal roots [28], high nitrogen treatment was used to suppress nodulation, a measure which can be expected to reduce but not eliminate nodulation. Finally, Guillotin et al. [28] presented data for the induction of NIN by 'Myc-LCOs', an equimolar mixture of LCOs produced in bacteria [44] whose biological relevance is still being debated. Indeed, considering the evidence presented here and studies cited herein, the relevance of 'Myc-LCOs' to mycorrhiza is questionable. On this point, it is worth noting that the mixture used contains sulfated LCOs that are structurally very similar to S. meliloti Nod factors.

In addition to the data presented here, recent phylogenetic studies also contradict a role for NIN in mycorrhization $[23,45]$. The weight of phylogenetic research suggests a single phylogenetic origin of nodulation with subsequent losses. This was evidenced by the loss of several nodulation-specific genes, including NIN, in almost all the non-nodulating plant species tested, despite the fact that the majority of these are able to form symbiosis with AM fungi $[23,24]$. This suggests that NIN's role in nodulation is highly specific and refutes a direct role in mycorrhization.

\section{Materials and Methods}

\subsection{Plant Material}

M. truncatula Jemalong A17 [46] and M. truncatula ssp. tricycla R108 seedlings [47] were used in this study. The nin-1 allele is the result of EMS mutagenesis in the WT A17 background and has an $11 \mathrm{bp}$ deletion starting at position 1850. The nin-2 allele is a Tnt1 transposon insertion line in the R108 WT background with the insertion lying 20bp upstream of the ATG [9].

\subsection{Seedling Germination}

Seed pods were collected from mature dried M. truncatula plants. These were dried for 3-7 days in a $37^{\circ} \mathrm{C}$ incubator. The seeds were extracted by crushing the pods with wooden blocks covered in corrugated rubber. The scarification and sterilisation of seeds were performed as described previously [29]. The seeds were then plated on Distilled Water Agar (DWA) plates and inverted to allow for downward root growth. Seeds were put in the dark at $4{ }^{\circ} \mathrm{C}$ for stratification for 7 days before transplanting to a soil substrate.

\subsection{Production of Mycorrhizal Inoculum}

To produce an inoculum free from contaminating microbes, particularly rhizobia, all working surfaces, trays, instruments etc. are washed down with $70 \%$ ethanol and ethanol sterilized gloves were worn. Terragreen (Oil-Dri Ltd., Wisbech Cambs, UK), sharp sand and Levington's F1 low nutrient compost (Scotts, Suffolk, UK) at a ratio of 2:2:1 was autoclaved. The seed trays were filled with this soil substrate and approximately 300 chive seeds were evenly distributed on the surface and then lightly 
covered with soil. This was watered well with $\mathrm{dH}_{2} \mathrm{O}$ and a plastic transparent lid was applied to prevent cross-contamination by rhizobia in the growth rooms. One week after sowing, each germinated plant was inoculated at the base of the stem with 200 sterile Rhizophagus irregularis spores DAOM 197198 purchased from Symplanta (Darmstadt, Germany). The plants were grown for eight weeks in the same conditions as the $M$. truncatula plants, being watered to prevent the soil substrate from drying out. After eight weeks, the chive shoots were removed, and the soil substrate/chive root mixture left was then mixed by hand to create a homogenous mixture. To reduce the risk of rhizobial contamination, the inoculum was then transferred into sealed plastic bags. To increase the inoculum in a sterile manner the previously made chive inoculum was evenly spread on the bottom of a seed tray, ensuring an even distribution of chive roots, using 20\% of the volume of the tray. A 1:1 mixture of Terra green and sharp sand was added on top ( $80 \%$ of total soil volume) and chive seeds were sown with growth conditions as before. The inoculum was then harvested eight weeks after planting as described above and stored in the dark at $4{ }^{\circ} \mathrm{C}$ in sealed plastic bags.

\subsection{Nodulation}

For nodulation, Sinorhizobium meliloti Rm1021 strains were grown overnight at $28{ }^{\circ} \mathrm{C}$ with shaking. The seedlings were inoculated with $1 \mathrm{~mL}$ of rhizobia at a final absorbance of 0.02 at $\mathrm{OD}_{600}$ diluted in water one day after transplanting.

\subsection{Mycorrhization}

To compare the differences in arbuscule formation by the fungus $R$. irregularis, the seedlings were germinated as described. The seedlings were then transferred to 1:1 terragreen:sharp sand low nutrient growth medium mixed with $20 \%$ chive inoculum containing roots of chive plants infected with spores of $R$. irregularis. The plants were covered with a lid for the first week only to maintain humidity and then were allowed to grow for 2 to 4 weeks before harvesting the root tissue. The roots were washed and approximately one inch of each sample from around two thirds of the total root length was collected for analysis. The fungus was visualized using an ink staining protocol [48]. The arbuscule frequency was then scored using the gridline intersect method [49] under a Nikon Eclipse E800 light microscope with a Pixera Pro 600ES camera.

Supplementary Materials: The following are available online at http://www.mdpi.com/2223-7747/9/1/71/s1, Supplemental S1: Genes deregulated in nin that are upregulated in mycorrhizal roots.

Author Contributions: Conceptualization, J.D.M.; methodology, D.R.C. and C.-W.L.; data curation, A.K.; writing, J.D.M., A.K. and P.X. All authors have read and agreed to the published version of the manuscript.

Funding: This research was funded by the Shanghai Engineering Research Center of Plant Germplasm Resources (grant no. 17DZ2252700), the National Key R\&D Program of China (grant no. 2016YFA0500500), the Biotechnology and Biological Sciences Research Council (grant no. BB/L010305/1 [David Phillips Fellowship]).

Conflicts of Interest: The authors declare no conflict of interest.

\section{References}

1. Brundrett, M.C.; Tedersoo, L. Evolutionary history of mycorrhizal symbioses and global host plant diversity. New Phytol. 2018, 220, 1108-1115. [CrossRef] [PubMed]

2. Choi, J.; Summers, W.; Paszkowski, U. Mechanisms Underlying Establishment of Arbuscular Mycorrhizal Symbioses. Annu. Rev. Phytopathol. 2018, 56, 135-160. [CrossRef] [PubMed]

3. Kamel, L.; Keller-Pearson, M.; Roux, C.; Ané, J.M. Biology and evolution of arbuscular mycorrhizal symbiosis in the light of genomics. New Phytol. 2017, 213, 531-536. [CrossRef] [PubMed]

4. Ferguson, B.J.; Mens, C.; Hastwell, A.H.; Zhang, M.; Su, H.; Jones, C.H.; Chu, X.; Gresshoff, P.M. Legume nodulation: The host controls the party. Plant Cell Environ. 2019, 42, 41-51. [CrossRef] [PubMed]

5. Liu, C.W.; Breakspear, A.; Stacey, N.; Findlay, K.; Nakashima, J.; Ramakrishnan, K.; Liu, M.; Xie, F.; Endre, G.; de Carvalho-Niebel, F.; et al. A protein complex required for polar growth of rhizobial infection threads. Nat. Commun. 2019, 10, 2848. [CrossRef] [PubMed] 
6. Zhang, X.; Han, L.; Wang, Q.; Zhang, C.; Yu, Y.; Tian, J.; Kong, Z. The host actin cytoskeleton channels rhizobia release and facilitates symbiosome accommodation during nodulation in Medicago truncatula. New Phytol. 2019, 221, 1049-1059. [CrossRef] [PubMed]

Buhian, W.P.; Bensmihen, S. Mini-review: Nod factor regulation of phytohormone signaling and homeostasis during rhizobia-legume symbiosis. Front. Plant Sci. 2018, 9, 10. [CrossRef]

7. Liu, C.W.; Murray, J.D. The role of flavonoids in nodulation host-range specificity: An update. Plants 2016, 5, 33. [CrossRef]

8. Schauser, L.; Roussis, A.; Stiller, J.; Stougaard, J. A plant regulator controlling development of symbiotic root nodules. Nature 1999, 402, 191-195. [CrossRef]

9. Marsh, J.F.; Rakocevic, A.; Mitra, R.M.; Brocard, L.; Sun, J.; Eschstruth, A.; Long, S.R.; Schultze, M.; Ratet, P.; Oldroyd, G.E.D. Medicago truncatula NIN is essential for rhizobial-independent nodule organogenesis induced by autoactive calcium/calmodulin-dependent protein kinase. Plant Physiol. 2007, 144, 324-335. [CrossRef]

10. Middleton, P.H.; Jakab, J.; Penmetsa, R.V.; Starker, C.G.; Doll, J.; Kaló, P.; Prabhu, R.; Marsh, J.F.; Mitra, R.M.; Kereszt, A.; et al. An ERF transcription factor in Medicago truncatula that is essential for nod factor signal transduction. Plant Cell 2007, 19, 1221-1234. [CrossRef] [PubMed]

11. Kaló, P.; Gleason, C.; Edwards, A.; Marsh, J.; Mitra, R.M.; Hirsch, S.; Jakab, J.; Sims, S.; Long, S.R.; Rogers, J.; et al. Nodulation signaling in legumes requires NSP2, a member of the GRAS family of transcriptional regulators. Science 2005, 308, 1786-1789. [CrossRef] [PubMed]

12. Oldroyd, G.E.D.; Long, S.R. Identification and characterization of nodulation-signaling pathway 2, a gene of Medicago truncatula involved in nod factor signaling. Plant Physiol. 2003, 131, 1027-1032. [CrossRef] [PubMed]

13. Heckmann, A.B.; Lombardo, F.; Miwa, H.; Perry, J.A.; Bunnewell, S.; Parniske, M.; Wang, T.L.; Downie, J.A. Lotus japonicus nodulation requires two GRAS domain regulators, one of which is functionally conserved in a non-legume. Plant Physiol. 2006, 142, 1739-1750. [CrossRef]

14. Smit, P.; Raedts, J.; Portyanko, V.; Debellé, F.; Gough, C.; Bisseling, T.; Geurts, R. NSP1 of the GRAS protein family is essential for rhizobial nod factor-induced transcription. Science 2005, 308, 1789-1791. [CrossRef]

15. Combier, J.P.; Frugier, F.; De Billy, F.; Boualem, A.; El-Yahyaoui, F.; Moreau, S.; Vernié, T.; Ott, T.; Gamas, P.; Crespi, M.; et al. MtHAP2-1 is a key transcriptional regulator of symbiotic nodule development regulated by microRNA169 in Medicago truncatula. Genes Dev. 2006, 20, 3084-3088. [CrossRef]

16. Combier, J.P.; De Billy, F.; Gamas, P.; Niebel, A.; Rivas, S. Trans-regulation of the expression of the transcription factor MtHAP2-1 by a uORF controls root nodule development. Genes Dev. 2008, 22, 1549-1559. [CrossRef]

17. Laporte, P.; Lepage, A.; Fournier, J.; Catrice, O.; Moreau, S.; Jardinaud, M.F.; Mun, J.H.; Larrainzar, E.; Cook, D.R.; Gamas, P.; et al. The CCAAT box-binding transcription factor NF-YA1 controls rhizobial infection. J. Exp. Bot. 2014, 65, 481-944. [CrossRef]

18. Borisov, A.Y.; Madsen, L.H.; Tsyganov, V.E.; Umehara, Y.; Voroshilova, V.A.; Batagov, A.O.; Sandal, N.; Mortensen, A.; Schauser, L.; Ellis, N.; et al. The Sym35 gene required for root nodule development in pea is an ortholog of Nin from Lotus japonicus. Plant Physiol. 2003, 131, 1009-1017. [CrossRef]

19. Chardin, C.; Girin, T.; Roudier, F.; Meyer, C.; Krapp, A. The plant RWP-RK transcription factors: Key regulators of nitrogen responses and of gametophyte development. J. Exp. Bot. 2014, 65, 5577-5587. [CrossRef]

20. Castaings, L.; Camargo, A.; Pocholle, D.; Gaudon, V.; Texier, Y.; Boutet-Mercey, S.; Taconnat, L.; Renou, J.P.; Daniel-Vedele, F.; Fernandez, E.; et al. The nodule inception-like protein 7 modulates nitrate sensing and metabolism in Arabidopsis. Plant J. 2009, 57, 426-435. [CrossRef] [PubMed]

21. Lin, J.S.; Li, X.; Luo, Z.L.; Mysore, K.S.; Wen, J.; Xie, F. NIN interacts with NLPs to mediate nitrate inhibition of nodulation in Medicago truncatula. Nat. Plants 2018, 4, 942-952. [CrossRef] [PubMed]

22. Nishida, H.; Tanaka, S.; Handa, Y.; Ito, M.; Sakamoto, Y.; Matsunaga, S.; Betsuyaku, S.; Miura, K.; Soyano, T.; Kawaguchi, M.; et al. A NIN-LIKE PROTEIN mediates nitrate-induced control of root nodule symbiosis in Lotus japonicus. Nat. Commun. 2018, 9, 499. [CrossRef] [PubMed]

23. Van Velzen, R.; Holmer, R.; Bu, F.; Rutten, L.; van Zeijl, A.; Liu, W.; Santuari, L.; Cao, Q.; Sharma, T.; Shen, D.; et al. Comparative genomics of the nonlegume Parasponia reveals insights into evolution of nitrogen-fixing rhizobium symbioses. Proc. Natl. Acad. Sci. USA 2018, 115, 4700-4709. [CrossRef] 
24. Griesmann, M.; Chang, Y.; Liu, X.; Song, Y.; Haberer, G.; Crook, M.B.; Billault-Penneteau, B.; Lauressergues, D.; Keller, J.; Imanishi, L.; et al. Phylogenomics reveals multiple losses of nitrogen-fixing root nodule symbiosis. Science 2018, 361, eaat1743. [CrossRef]

25. Liu, C.W.; Breakspear, A.; Guan, D.; Cerri, M.R.; Jackson, K.; Jiang, S.; Robson, F.; Radhakrishnan, G.V.; Roy, S.; Bone, C.; et al. NIN acts as a network hub controlling a growth module required for rhizobial infection. Plant Physiol. 2019, 179, 1704-1722. [CrossRef]

26. Xie, F.; Murray, J.D.; Kim, J.; Heckmann, A.B.; Edwards, A.; Oldroyd, G.E.D.; Downie, J.A. Legume pectate lyase required for root infection by rhizobia. Proc. Natl. Acad. Sci. USA 2012, 109, 633-638. [CrossRef]

27. Soyano, T.; Kouchi, H.; Hirota, A.; Hayashi, M. NODULE INCEPTION Directly Targets NF-Y Subunit Genes to Regulate Essential Processes of Root Nodule Development in Lotus japonicus. PLoS Genet. 2013, 9, e1003352. [CrossRef]

28. Guillotin, B.; Couzigou, J.M.; Combier, J.P. NIN is involved in the regulation of arbuscular mycorrhizal symbiosis. Front. Plant Sci. 2016, 7, 1704. [CrossRef]

29. Breakspear, A.; Liu, C.; Roy, S.; Stacey, N.; Rogers, C.; Trick, M.; Morieri, G.; Mysore, K.S.; Wen, J.; Oldroyd, G.E.D.; et al. The root hair "infectome" of Medicago truncatula uncovers changes in cell cycle genes and reveals a requirement for auxin signaling in rhizobial infection. Plant Cell 2014, 26, 4680-4701. [CrossRef]

30. Roux, B.; Rodde, N.; Jardinaud, M.F.; Timmers, T.; Sauviac, L.; Cottret, L.; Carrère, S.; Sallet, E.; Courcelle, E.; Moreau, S.; et al. An integrated analysis of plant and bacterial gene expression in symbiotic root nodules using laser-capture microdissection coupled to RNA sequencing. Plant J. 2014, 77, 817-837. [CrossRef] [PubMed]

31. Medicago truncatula Gene Expression Atlas. Available online: https://mtgea.noble.org/v3/ (accessed on 23 December 2019).

32. Lotus japonicus Gene Expression Atlas. Available online: https://ligea.noble.org/v2/index.php (accessed on 23 December 2019).

33. Gaude, N.; Bortfeld, S.; Duensing, N.; Lohse, M.; Krajinski, F. Arbuscule-containing and non-colonized cortical cells of mycorrhizal roots undergo extensive and specific reprogramming during arbuscular mycorrhizal development. Plant J. 2012, 69, 510-528. [CrossRef] [PubMed]

34. Gomez, S.K.; Javot, H.; Deewatthanawong, P.; Torres-Jerez, I.; Tang, Y.; Blancaflor, E.B.; Udvardi, M.K.; Harrison, M.J. Medicago truncatula and Glomus intraradices gene expression in cortical cells harboring arbuscules in the arbuscular mycorrhizal symbiosis. BMC Plant Biol. 2009, 9, 10. [CrossRef] [PubMed]

35. Guether, M.; Balestrini, R.; Hannah, M.; He, J.; Udvardi, M.K.; Bonfante, P. Genome-wide reprogramming of regulatory networks, transport, cell wall and membrane biogenesis during arbuscular mycorrhizal symbiosis in Lotus japonicus. New Phytol. 2009, 182, 200-212. [CrossRef]

36. De Bang, T.C.; Lundquist, P.K.; Dai, X.; Boschiero, C.; Zhuang, Z.; Pant, P.; Torres-Jerez, I.; Roy, S.; Nogales, J.; Veerappan, V.; et al. Genome-wide identification of medicago peptides involved in macronutrient responses and nodulation. Plant Physiol. 2017, 175, 1669-1689. [CrossRef]

37. Luginbuehl, L.H.; Menard, G.N.; Kurup, S.; Van Erp, H.; Radhakrishnan, G.V.; Breakspear, A.; Oldroyd, G.E.D.; Eastmond, P.J. Fatty acids in arbuscular mycorrhizal fungi are synthesized by the host plant. Science 2017, 356, 1175-1178. [CrossRef]

38. M. truncatula Small Secreted Peptide Database. Available online: http://mtsspdb.noble.org/database/ (accessed on 23 December 2019).

39. Saur, I.M.L.; Oakes, M.; Djordjevic, M.A.; Imin, N. Crosstalk between the nodulation signaling pathway and the autoregulation of nodulation in Medicago truncatula. New Phytol. 2011, 190, 865-874. [CrossRef]

40. Soyano, T.; Hirakawa, H.; Sato, S.; Hayashi, M.; Kawaguchi, M. NODULE INCEPTION creates a long-distance negative feedback loop involved in homeostatic regulation of nodule organ production. Proc. Natl. Acad. Sci. USA 2014, 111, 14607-14612. [CrossRef]

41. Tsyganov, V.E.; Voroshilova, V.A.; Kukalev, A.S.; Azarova, T.S.; Yakobi, L.M.; Borisov, A.Y.; Tikhonovich, I.A. Pisum sativum L. Genes Sym14 and Sym35 Control Infection Thread Growth Initiation during the Development of Symbiotic Nodules. Russ. J. Genet. 1999, 35, 284-291.

42. Geurts, R.; Xiao, T.T.; Reinhold-Hurek, B. What Does It Take to Evolve A Nitrogen-Fixing Endosymbiosis? Trends Plant Sci. 2016, 21, 199-208. [CrossRef] 
43. Takeda, N.; Tsuzuki, S.; Suzaki, T.; Parniske, M.; Kawaguchi, M. CERBERUS and NSP1 of Lotus japonicus are common symbiosis genes that modulate arbuscular mycorrhiza development. Plant Cell Physiol. 2013, 54, 1711-1723. [CrossRef] [PubMed]

44. Maillet, F.; Poinsot, V.; André, O.; Puech-Pagés, V.; Haouy, A.; Gueunier, M.; Cromer, L.; Giraudet, D.; Formey, D.; Niebel, A.; et al. Fungal lipochitooligosaccharide symbiotic signals in arbuscular mycorrhiza. Nature 2011, 469, 58-63. [CrossRef] [PubMed]

45. Soltis, D.E.; Soltis, P.S.; Morgan, D.R.; Swensen, S.M.; Mullin, B.C.; Dowd, J.M.; Martin, P.G. Chloroplast gene sequence data suggest a single origin of the predisposition for symbiotic nitrogen fixation in angiosperms. Proc. Natl. Acad. Sci. USA 1995, 92, 2647-2651. [CrossRef] [PubMed]

46. Barker, D.G.; Bianchi, S.; Blondon, F.; Dattée, Y.; Duc, G.; Essad, S.; Flament, P.; Gallusci, P.; Génier, G.; Guy, P.; et al. Medicago truncatula, a model plant for studying the molecular genetics of the Rhizobium-legume symbiosis. Plant Mol. Biol. Rep. 1990, 8, 40-49. [CrossRef]

47. Hoffmann, B.; Trinh, T.H.; Leung, J.; Kondorosi, A.; Kondorosi, E. A new Medicago truncatula line with superior in vitro regeneration, transformation, and symbiotic properties isolated through cell culture selection. Mol. Plant-Microbe Interact. 1997, 10, 307-315. [CrossRef]

48. Vierheilig, H.; Coughlan, A.P.; Wyss, U.; Piché, Y. Ink and vinegar, a simple staining technique for arbuscular-mycorrhizal fungi. Appl. Environ. Microbiol. 1998, 64, 5004-5007. [CrossRef]

49. Giovannetti, M.; Mosse, B. An evaluation of techniques for measuring vesicular arbuscular mycorrhizal infection in roots. New Phytol. 1980, 84, 489-500. [CrossRef]

(C) 2020 by the authors. Licensee MDPI, Basel, Switzerland. This article is an open access article distributed under the terms and conditions of the Creative Commons Attribution (CC BY) license (http://creativecommons.org/licenses/by/4.0/). 